\title{
Resistance to Mobile Banking Adoption in a Developing Country: Evidence from Modified TAM
}

\author{
Imtiaz Arif* $\quad$ Sahar Afshan ${ }^{\dagger} \quad$ Arshian Sharif $\ddagger$
}

\begin{abstract}
Mobile banking is an emerging concept with great potential but it is facing lower rate of diffusion. This study examines the perception and intention aspects of mobile banking adoption in Pakistan. Modified Technology Acceptance Model is used with the integration of four perceived risk dimensions (financial, privacy, time and security). A sample of valid 389 responses was drawn from the mobile subscribers of Karachi. The techniques of both exploratory and confirmatory factor analyses were employed to assess the reliability and validity of the measurement model. The structural equation modeling method was also applied to investigate the hypothetical framework with the help of literature's recommended goodness-of-fit measurements. The results indicate a negative association of financial and privacy risks with the attitude towards mobile banking technology. Furthermore, perceived ease of use and perceived usefulness established the significant positive impact on people's attitude towards mobile banking. Likewise, attitude towards mobile banking is also found to significantly influence the adoption intention of technology. The findings are favorable for banks that are pursuing mobile banking in designing strategies for enhancing users' acceptance of mobile banking in Pakistan.
\end{abstract}

Keywords: Mobile banking, modified TAM, financial risk, privacy risk, time risk and security risk.

\section{Introduction}

The progress of technological innovations have had a huge impact on the modern era of banking sector. The traditional distribution of banking industry was restricted to physical branches that have high fixed cost. The continual development of information technology not only enables banks to reduce their unit cost but also provides them the required efficiency for global competition. Since 1980s, modern banking has achieved the desired level of service quality by using technology enhanced systems from Automated Teller Machine (ATM) to modern 24/7 e-banking (Liao \& Cheung, 2002). These electronic channels have supported banks in attaining greater customer satisfaction as well as increasing customer convenience and profitability(Karjaluoto, Püschel, Afonso Mazzon, \& Hernandez, 2010).

The branch less banking technology, which started from the Internet, has now emerged as vastly innovative and updated mobile banking. Mobile banking refers to "a channel whereby the consumer interacts with a bank via a mobile device, such as a mobile phone or personal digital

\footnotetext{
*Director Academics, IQRA University, Karachi-75300, Pakistan. E-mail: arif.i@iuk.edu.pk

${ }^{\dagger}$ Lecturer, Dadabhoy Institute of Higher Education, Karachi, Pakistan.

E-mail: sahar_khan09@hotmail.com

${ }^{\ddagger}$ Assistant Manager, Research \& Publication, IQRA University, Karachi-75300, Pakistan.

E-mail: arshian.aslam@gmail.com
} 
assistant; in that sense it can be seen as a subset of electronic banking and an extension of internet banking with its own unique characteristics" (Laukkanen \& Pasanen, 2008). Mobile banking has huge potential, since it follows the success of internet banking (Brown, Cajee, Davies, \& Stroebel, 2003). M-banking is not only considered a natural evolution of e-banking, but it is thought to be a better digital alternative to other traditional banking channels such as ATMs, internet banking and physical branches.

The penetration of cellular banking in advanced countries is elevated for obvious reasons; however, it is also gaining acceptance in the developing economies. In Pakistan, where a large number of commercial banks are operating in a great unbanked market, there exists an acceleration in the growth trend of mobile banking. During the first quarter of 2014, mobile phone banking transactions were recorded as 9.56 million with $27 \%$ growth in volume as compared to the last quarter. In terms of value, the transactions rose to 21.4 billion, showing a whopping increase of $51 \%$ (SBP, 2014). The benefits of convenience, accessibility and personalization in mobile banking suggested its positive effects on the acceptance of mobile banking of the country.

Despite the various advantages of mobile banking, many researches believe that it has not spread and acknowledged as expected(Kim, Shin, \& Lee, 2009; Laukkanen, 2007; Laforet \& Li, 2005). The consideration of consumer perspective has highlighted a number of barriers in the adoption of mobile banking by the end users (Karjaluoto, Riquelme, \& Rios, 2010). These barriers mainly include privacy and security concerns. Overcoming these barriers will assist banks to generate wider acceptance of mobile banking and stimulate adoption intention in the consumers. If banks want to attract the consumers to use their cell phones for banking activities, they must consider providing ease of operations, relative advantages (usefulness) and reduced uncertainties in their banking activities as compared to other banking channels (Karjaluoto, Riquelme, \& Rios, 2010).

Approximately $80 \%$ of all transactions conducted through branch less banking in Pakistan are conducted through over the counter (OTC) instead of mobile wallet (SBP, 2014). In the market of 135.76 million mobile subscribers, only $14 \%$ have adopted mobile banking which seems inadequate. This has highlighted the risk concerns on the part of the consumers regarding their $\mathrm{m}$-wallet accounts. The leading objective of this study is to explore the main reasons behind the reluctance in consumer acceptance of mobile banking of the country. The findings of the study will assist banks in the enhancement of mobile banking growth of the country and will present at framework for designing the right marketing strategies for the improvement in the adoption of mobile banking in the country.

\section{Literature Review}

\section{Theoretical Background}

The role of technology has achieved great importance and priority in modern banking. The literature of branch less banking is full of various theories that can discover critical factors which influence the acceptance of technologies in banking. This paper utilizes the theory of Davis (1989) i.e. Technology Acceptance Model (henceforth, TAM) with the integration of risk dimension in users' acceptance of mobile banking. TAM is a multivariable model that predicts the users' intention on the basis of their perception (Afshan \& Sharif, 2016; Raza \& Hanif, 2013). It implies that attitudes predict intentions, and intentions predict behavior. This model underlines that adoption is an outcome of intention which is determined through the usefulness and ease of use of a technology. The dimensions of TAM thus include usefulness, ease of use, attitude to use, 
intention to use and actual use. TAM is renowned as a highly predictive model with simplicity in term of variables (Agarwal \& Prasad, 1999). This model has attained vast acceptance in the literature, especially regarding the adoption of information technology(Lederer, Maupin, Sena, \& Zhuang, 2000; Venkatesh, Morris, Davis, \& Davis, 2003; Raza \& Hanif, 2013).

Figure 1: Technology Acceptance Model

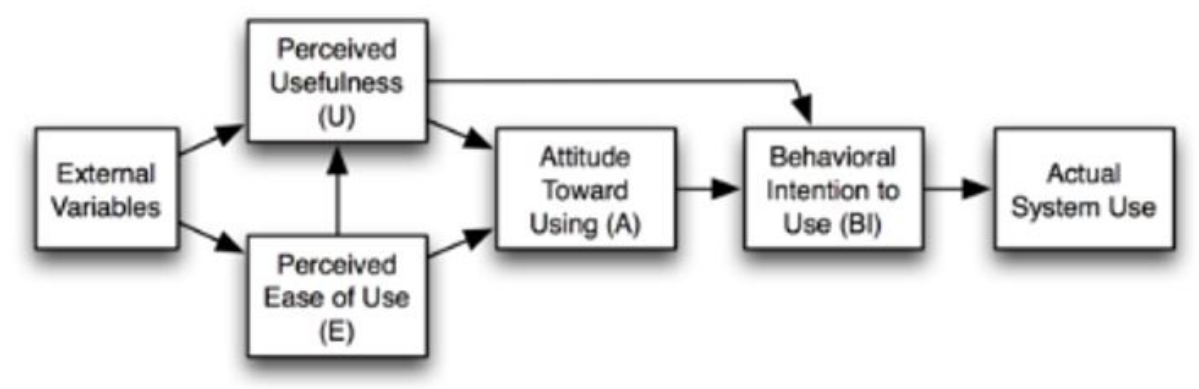

\section{Empirical Studies and Research Hypothesis}

Ample previous studies have predicted the numerous dimensions of mobile banking acceptance. This study focuses on predicting the role of perceived usefulness, perceived ease of use and perceived risk dimensions (financial, security, privacy and time). Following is a brief discussion of the empirical evidence of numerous studies encompassing the contribution of usefulness, ease of use and perceived risk in explaining mobile banking adoption.

\section{Perceived Usefulness}

Perceived usefulness refers to the degree to which a technology will be supportive in augmenting its performance (Davis, 1989). Tobbin (2012) examines the acceptance of mobile banking in the rural area of Ghana among un-banked individuals. The study based its conclusion on the results derived from the group interviews of ninety seven un-banked people distributed in a total of eight groups. The results suggested that usefulness implies a substantial contribution in the adoption intention of rural un-banked segment of Ghana. Sun, Goh, Fam, Xue, and Xue (2012) in their study also found that consumer intention to adopt mobile banking technology mainly depends on perceived usefulness. In Germany, Karjaluoto, Koenig-Lewis, Palmer, and Moll (2010) investigated the barriers which are faced by new users in the acceptance of mobile banking technology, using the sample size of 155 respondents. The results confirmed the significant contribution of usefulness in mobile banking adoption. Similar results were found in the studies of (Akturan \& Tezcan, 2012; Zhou, 2011; Karjaluoto, Riquelme, \& Rios, 2010; Karjaluoto, Koenig-Lewis, et al., 2010). In this study, we posit the influence of perceived usefulness on mobile banking as the following:

H1: Customers' attitude towards using mobile banking is positively influenced by perceived usefulness. 
H2: Customers' attitude towards mobile banking is positively influenced by perceived usefulness.

\section{Perceived Ease of Use}

Another widely established aspect of mobile banking acceptance is perceived ease of use. Perceived ease of use refers to "the degree to which a person believes that using a particular system would be free of physical and mental effort" (Davis, 1989). In Singapore, Karjaluoto, Riquelme, and Rios (2010) reported the significant role of ease of use in m-banking adoption of female mobile banking users. Akturan and Tezcan (2012) also recognized the significant contribution of ease of use in mobile banking adoption in their research of mobile banking acceptance in Turkey. Similarly, Adams, Nelson, and Todd (1992) also reported the association of ease of use with information technology acceptance by employing technology acceptance framework. Similar empirical evidence was found in the studies of (Tobbin, 2012; Püschel, Afonso Mazzon, \& Mauro, 2010; Davis, Bagozzi, \& Warshaw, 1989).

We therefore posit the following:

H3: Customers' attitude towards using mobile banking is positively influenced by perceived ease of use.

H4: Consumers' perceived usefulness is positively influenced by their perceived ease of use.

\section{Perceived Risk}

Perceived risk is defined as the level of uncertainty perceived by the end users in a specific purchase situation (Cox \& Rich, 1964). Perceived risk for branch less banking users refers to the expectation of loss in search of a favored result from utilizing e-banking services (Yousafzai, Pallister, \& Foxall, 2003). Several studies have recognized perceived risk as the fundamental barrier of mobile banking adoption. Consumers' acceptance of mobile banking \& payments is impeded by the security concerns and the likelihood of hackers accessing consumers' phones remotely (FRB, 2012). Al Kailani and Kumar (2011) stated that in a society where risk aversion is on the greater side, electronic buying has a negative association with perceived risk thus negatively impacting e-commerce. Cope, Rock, and Schmeiser (2013) investigated customers' perception of risk and level of risk tolerance in the adoption of mobile banking in Washington. The study found that the banking customers who believe that mobile banking is unsafe want to adopt m-banking at much lower rate as compared to those who consider m-banking safe. It further explained that people with higher level of risk tolerance are more eager to adopt mobile banking even after controlling their perception of the safety associated with m-banking.

In Taiwan, Chen (2013) investigated the role of perceived risk in the adoption of mobile banking services by utilizing several dimensions of risk in Diffusion of Innovation (DOI) modeling. The risk dimensions included financial risk, performance risk, time risk, psychology risk, and privacy risk. The study utilizing the sample of 610 respondents concluded at significant negative influence of perceived risk on the attitude as well as adoption intention of mobile banking technology. Similar results were found in the studies of (Akturan \& Tezcan, 2012; Zhou, 2011; Karjaluoto, Riquelme, \& Rios, 2010). 
Perceived risk, however, is not a uni-dimensional concept. Literature has highlighted several dimensions of perceived risk. Pavlou (2003); Littler and Melanthiou (2006) hypothesized risk in five dimensions of financial, performance, time, psychological, and security risks. Akturan and Tezcan (2012) measured perceived risk in six dimensions of financial, time privacy, social, security and performance risk. Aldas-Manzano, Ruiz-Mafe, Sanz-Blas, and Lassala-Navarré (2011) used two dimensions of measuring perceived risk i.e. privacy and security risks. We have hypothesized four dimensions of perceived risk in the present study. These dimensions include financial risk, privacy risk, time risk and security risk. Following table presents the definitions for the studied dimensions of perceived risk utilized in this study.

Table 1

Risk Dimension Definitions

\begin{tabular}{cl}
\hline Financial Risk & $\begin{array}{l}\text { The probable financial expenses which are related with the preliminary purchase price } \\
\text { and maintenance cost of the product }\end{array}$ \\
\hline Time Risk & $\begin{array}{l}\text { The time risk can be defined as the possibility that using a technology may require to } \\
\text { learn it and this learning may require too much time }\end{array}$ \\
\hline Privacy Risk & The possibility of losing the personal information while using the product \\
\hline Security Risk & $\begin{array}{l}\text { The possibility of losing the control over a transaction and also the financial } \\
\text { information }\end{array}$ \\
\hline Source: (Akturan \& Tezcan, 2012)
\end{tabular}

We thus posit the following:

H5: Customers' attitude towards using mobile banking is negatively influenced by financial risk.

H6: Customers' attitude towards using mobile banking is negatively influenced by privacy risk.

H7: Customers' attitude towards using mobile banking is negatively influenced by time risk.

H8: Customers' attitude towards using mobile banking is negatively influenced by security risk.

H9: Mobile banking adoption intention is positively influenced by customers' attitude towards using mobile banking.

\section{Methodology}

\section{Sample, Data Collection and Screening}

The present research based its analysis on the primary data collected from the mobile subscribers in Karachi. The data was collected from non-users of mobile banking through 
a structured questionnaire. A total of 500 questionnaires were filled from the period of June 2014 to August 2014. The responses were checked for missing values and replaced with series mean method (Lynch, 2003). The data screening also examined potential outliers. Univariate outliers are detected through box-plot examination and resulted in 93 outliers to be removed. For multivariate outliers, the usual measure is Mahalanobis distance. The fallout of D2 $<0.001$ threshold value for designation resulted in 18 Multivariate sure outliers which were identified and dropped from the data set distance (Hair, Black, Babin, Anderson, \& Tatham, 2006; Tabachnick, Fidell, et al., 2007). Thus the final count left 389 valid responses. The sample size of 300 or above is considered good. In our case, the sample size of 363 shows the sufficiency of sample size (Hair et al., 2006; Heikki, Cruz, Barretto Filgueiras Neto, Muñoz-Gallego, \& Laukkanen, 2010; Ali \& Raza, 2015).

Figure 2: Hypothesized model of the study

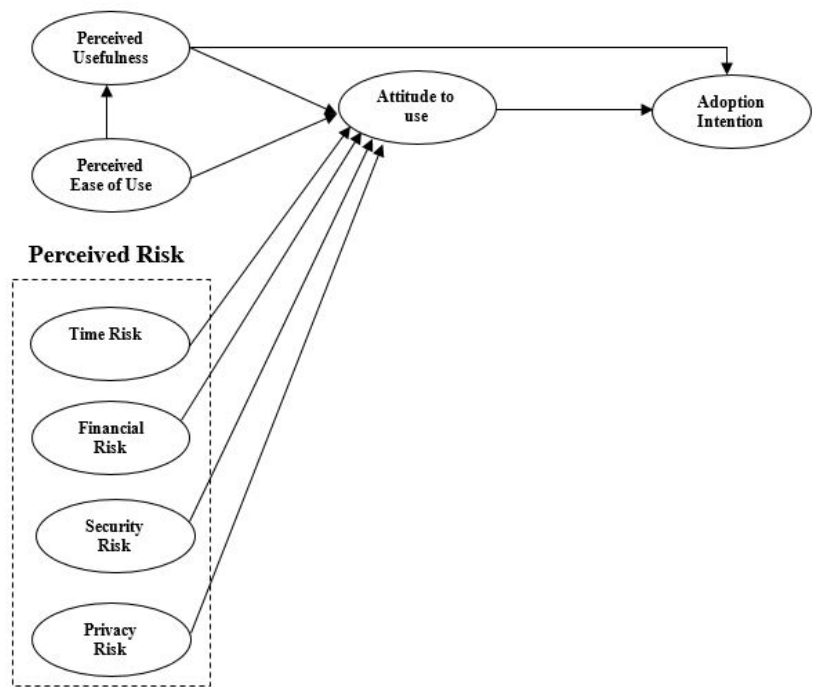

\section{Measures}

The questionnaire incorporated eight variables for present research that includes: Perceived Ease of Use (PEOU), Perceived Usefulness (PU), Perceived Financial Risk (FR), Perceived Security Risk (SR), Perceived Privacy Risk (PR), Perceived Time Risk (TR), Attitude to use Mobile Banking (AT) and Intention of Adoption of Mobile Banking (IA). The adopted questionnaire engrosses the attributes of these variables and is designed through five levels of Likert scale from $1=$ Strongly Disagree to $5=$ Strongly Agree. Table 2 displays the construction of adapted questionnaire with references. 


\section{Data Analysis and Results}

\section{Descriptive Statistics}

The data analysis in the study was performed using the software of SPSS 21 and AMOS 21 with a sample size of 389 . Table 3 presents the basic composition of the data. The research was carried out after checking the basic data analysis assumptions of; sample size, outliers, scales of the variables and multicollinearity (Hair et al., 2006; Fotopoulos \& Psomas, 2009). Displayed in table 4 are the results of mean, standard deviation, correlation \& reliability of the data. Hair, Black, Babin, Anderson, and Tatham (2010) stated that the issue of multicollinearity is said to be present in the data, if Pearsons r-value is above 0.90 . The highest Pearson's correlation value in table 3 is between adoption intention and perceived ease of use i.e. 0.554 , which still is less than 0.9 , suggesting no issue of multicollinearity among the constructs (Hair et al., 2010; Lin \& Lee, 2004).

\section{Exploratory Factor Analysis}

The present analysis used literature's excessively preferred principal components method (Guadagnoli \& Velicer, 1988; Schonemann, 1990; Steiger, 1990; Vellicer \& Jackson, 1990) to reduce its forty Likert based questionnaire items into eight best manageable proposed factors. To determine the adequacy of the sample, Kaiser-Meyer-Olkin was used which, showed the value of 0.843 which is above 0.7 and suggests that the sample is sufficient to run factor analysis (Leech, Barrett, \& Morgan, 2005; Barkus, Yavorsky, \& Foster, 2006; Ali \& Raza, 2015). Bartlett's test of sphericity (Approx. Chi-Square $=6981.26$, df $=703$, $\mathrm{p}<.000)$ depicts that the correlation matrix is significantly dissimilar from the identity matrix and correlation among variables is not zero (Leech et al., 2005).

Hair et al. (2010) recommended various criteria for factors extraction/retention. These include the methods of latent root, percentage of variance explained and scree test. Following these criteria, the analysis led to the retention of eight factors that together explain $64.52 \%$ of the total variance explained with Eigen values above 1.

The rotated component matrix consists of final thirty eight items with factor loadings above 0.68. According to the general rule of thumb, the factor loadings above 0.55 are considered good (Tabachnick et al., 2007). The resulting solution shown in table 5 doesn't show any cross loading among the items, indicating no issue of discriminant validity.

After exploratory factor analysis, the reliability through estimating Cronbach Alpha of each of the factor was computed as shown in Table 5. The overall reliability of thirty eight loaded items after exploratory factor analysis was found to be 0.764 . 
Table 2

Constructed Questionnaire and References

Financial risk

\section{References}

I think that the Services of mobile banking would not function well

I think that there would be problems with my financial transactions while using mobile banking

When using mobile banking, I am afraid that I will lose money due to any careless mistakes

I think my account information may get hacked and I may lose my money

I think that using mobile banking is financially risky would have to waste a lot of time fixing

Time risk

I think I would spend too much time learning how to use mobile banking

It takes time to use Mobile banking services

I think I would use mobile banking if someone would give me time and train me how to use it

Using a mobile banking service would lead to a loss of convenience for me because I would have

to waste a lot of time fixing payment errors

Because of some problems in the operator service/signal, I think that mobile banking would not run fast and cause time loss

\section{Security risk}

I do not trust the functionality of banking services through using a mobile device Going to the branch for making any transaction make me feel more safe as compare using to my own mobile account

I don't trust mobile banking as much as I trust a bank

I may worried about the security of mobile banking

Matters of security have an influence on using mobile banking

\section{Privacy risk}

Using mobile banking is financially in secure

I don't trust in the ability of mobile banking to protect my privacy

I don't trust in the technology used by mobile banking sector

A hacker may hack into my private information when using Mobile banking services

Personal information when using Mobile banking services may be stolen by others

\section{Attitude to use}

I think that using mobile banking is a good idea

I think that using mobile banking for financial transactions would be a wise idea

I think that using mobile banking is pleasant

In my opinion, it is desirable to use mobile banking

I will enjoy doing online transactions via Mobile banking services

Akturan and Tezcan (2012)

Akturan and Tezcan (2012)

Akturan and Tezcan (2012)

Akturan and Tezcan (2012)

Akturan and Tezcan (2012)

\section{Perceived usefulness}

I think that using mobile banking would enable me to Be accomplish my tasks more quickly

I think that using mobile banking would make it easier for me to carry out my tasks

I think mobile banking is useful

Overall, I think that using mobile banking is advantageous

I think mobile banking is useful in getting information such as bank statements.

Akturan and Tezcan (2012)

Chen (2013)

Chen (2013)

Akturan and Tezcan (2012)

Akturan and Tezcan (2012)

\section{Perceived ease of use}

I think that learning to use mobile banking would be easy

I think that learning to use mobile banking does not require a lot of mental effort

I think that it is easy to use mobile banking to accomplish my banking tasks

It would be easy for me to become skillful at using mobile banking.

Learning to use mobile banking is easy for me

Heikki et al. (2010)

Heikki et al. $(2010)$

Akturan and Tezcan (2012)

Akturan and Tezcan (2012)

Akturan and Tezcan (2012)

Akturan and Tezcan (2012)

Akturan and Tezcan (2012)

Akturan and Tezcan (2012)

Akturan and Tezcan (2012)

Chen (2013)

Chen (2013)

\section{Adoption intention}

I plan to use Mobile banking in future

I intend to use Mobile banking in future

If I have access to mobile banking, I will use it to complete my financial transactions

I'll use Mobile banking services on my job

I'll try to use Mobile banking services to complete financial transactions

Akturan and Tezcan (2012)

Akturan and Tezcan (2012)

Akturan and Tezcan (2012)

Akturan and Tezcan (2012) Chen (2013)

Akturan and Tezcan (2012)

Akturan and Tezcan (2012)

Akturan and Tezcan (2012)

Akturan and Tezcan (2012) Koenig-Lewis, Palmer, and Moll (2010)
Akturan and Tezcan (2012)

Akturan and Tezcan (2012)

Akturan and Tezcan (2012)

Koenig-Lewis et al. (2010)

Koenig-Lewis et al. (2010) 
Table 3

Composition of the Data

\begin{tabular}{|c|c|c|c|}
\hline \multirow{3}{*}{ Gender } & Male & 171 & $44 \%$ \\
\hline & Female & 218 & $56 \%$ \\
\hline & Total & 389 & $100 \%$ \\
\hline \multirow{4}{*}{ Age } & $20-30$ & 136 & $35 \%$ \\
\hline & $31-40$ & 126 & $32 \%$ \\
\hline & $41-50$ & 129 & $33 \%$ \\
\hline & Total & 389 & $100 \%$ \\
\hline \multirow{3}{*}{ Employment Status } & Employed & 311 & $80 \%$ \\
\hline & Unemployed & 78 & $20 \%$ \\
\hline & Total & 389 & $100 \%$ \\
\hline \multirow{7}{*}{ Salary Range } & 0 & 78 & $20 \%$ \\
\hline & $10000-20000$ & 51 & $13 \%$ \\
\hline & $21000-30000$ & 90 & $23 \%$ \\
\hline & $31000-40000$ & 93 & $24 \%$ \\
\hline & $41000-50000$ & 58 & $15 \%$ \\
\hline & 50000 above & 19 & $5 \%$ \\
\hline & Total & 389 & $100 \%$ \\
\hline
\end{tabular}

\section{Common Method Biasness}

The Common method biasness is considered to be one of the main sources of measurement errors in models (Podsakoff, MacKenzie, Lee, \& Podsakoff, 2003). Bagozzi, Yi, and Phillips (1991) noted that one of the main sources of systematic measurement error is method variance that may arise from a variety of sources. In order to check common method biasness of the data, Harman's one factor model was applied (Podsakoff et al., 2003). Using principal axis factoring framework, promax rotation and fixing the number of factors to 1 , total number of variance explained was found to be less than $50 \%$ i.e. $16.21 \%$. Thus the present data is concluded to be free of common method biasness issue.

Table 4

Mean, Standard deviation, Correlation and Reliability

\begin{tabular}{|c|c|c|c|c|c|c|c|c|c|c|}
\hline & Mean & S.D. & 1 & 2 & 3 & 4 & 5 & 6 & 7 & 8 \\
\hline Avg_PU & 2.7738 & 1.01587 & 1 & & & & & & & \\
\hline Avg_AT & 3.5352 & 0.57841 & $.194^{* *}$ & 1 & & & & & & \\
\hline Avg_AI & 3.0478 & 1.15664 & $.155^{* *}$ & $.464^{* *}$ & 1 & & & & & \\
\hline Avg_FR & 3.744 & 0.62164 & -0.046 & $-.253^{* *}$ & $-.309^{* *}$ & 1 & & & & \\
\hline Avg_SR & 3.7033 & 0.59371 & 0.026 & 0.061 & -0.003 & 0.087 & 1 & & & \\
\hline Avg_PR & 3.145 & 0.70999 & 0.051 & 0.017 & $-.183^{* *}$ & 0.054 & $-.208^{* *}$ & 1 & & \\
\hline Avg_TR & 3.4612 & 0.92405 & -0.047 & -0.024 & -0.012 & 0.063 & 0.048 & -0.053 & 1 & \\
\hline Avg_PEU & 2.9311 & 0.96323 & $.219 * *$ & $.432^{* *}$ & $.554^{* *}$ & $-.437 * *$ & 0.033 & 0.063 & -0.054 & 1 \\
\hline $\begin{array}{l}\text { Overall Cr } \\
* \text { Correla } \\
* * \text { Correlat } \\
* * * \text { Cronb } \\
\text { Notes: PU } \\
\mathrm{TR}=\text { Time }\end{array}$ & $\begin{array}{l}\text { nbach's } \\
\text { ion is sig } \\
\text { on is sig } \\
\text { ch Alpha } \\
\text { =Perceive } \\
\text { risk; PR }\end{array}$ & $\begin{array}{l}\text { ificant at } \\
\text { Reliability } \\
\text { Usefulne } \\
\text { Privacy r }\end{array}$ & $\begin{array}{l}\text { ity of th } \\
\text { e } 0.05 \text { le } \\
\text { e } 0.01 \text { le } \\
\text { oefficient } \\
\text { PEU }=\mathrm{F} \\
; \mathrm{AT}=\mathrm{A}\end{array}$ & $\begin{array}{l}\text { (1-tailed) } \\
\text { (2-tailed) }\end{array}$ & ale $=0.7$ & $64(38$ loa & ed items) & Secur & & \\
\hline
\end{tabular}


Table 5

Rotated Component Matri $x^{a}$

\begin{tabular}{|c|c|c|c|c|c|c|c|c|c|}
\hline & & 1 & 2 & 3 & 4 & 5 & 6 & 7 & 8 \\
\hline Security & SR4 & 0.824 & & & & & & & \\
\hline \multirow{4}{*}{ Risk } & SR5 & 0.805 & & & & & & & \\
\hline & SR2 & 0.801 & & & & & & & \\
\hline & SR1 & 0.801 & & & & & & & \\
\hline & SR3 & 0.771 & & & & & & & \\
\hline Privacy & PR1 & & 0.848 & & & & & & \\
\hline \multirow[t]{4}{*}{ Risk } & PR2 & & 0.823 & & & & & & \\
\hline & PR3 & & 0.807 & & & & & & \\
\hline & PR5 & & 0.732 & & & & & & \\
\hline & PR4 & & 0.690 & & & & & & \\
\hline Time & TR5 & & & 0.880 & & & & & \\
\hline \multirow[t]{4}{*}{ Risk } & TR4 & & & 0.798 & & & & & \\
\hline & TR1 & & & 0.752 & & & & & \\
\hline & TR3 & & & 0.752 & & & & & \\
\hline & TR2 & & & 0.735 & & & & & \\
\hline Adoption & $\mathrm{AI} 2$ & & & & 0.822 & & & & \\
\hline \multirow[t]{3}{*}{ Intention } & AI3 & & & & 0.819 & & & & \\
\hline & AI4 & & & & 0.805 & & & & \\
\hline & AI1 & & & & 0.785 & & & & \\
\hline Attitude & AT5 & & & & & 0.785 & & & \\
\hline \multirow[t]{5}{*}{ To use } & AT2 & & & & & 0.738 & & & \\
\hline & AT3 & & & & & 0.713 & & & \\
\hline & AT1 & & & & & 0.707 & & & \\
\hline & AT4 & & & & & 0.696 & & & \\
\hline & PU3 & & & & & & 0.818 & & \\
\hline Perceived & PU1 & & & & & & 0.794 & & \\
\hline \multirow[t]{4}{*}{ Usefulness } & PU4 & & & & & & 0.758 & & \\
\hline & PU2 & & & & & & 0.718 & & \\
\hline & PU5 & & & & & & 0.693 & & \\
\hline & FR2 & & & & & & & 0.738 & \\
\hline Financial & FR1 & & & & & & & 0.733 & \\
\hline \multirow[t]{3}{*}{ Risk } & FR3 & & & & & & & 0.697 & \\
\hline & FR4 & & & & & & & 0.696 & \\
\hline & FR5 & & & & & & & 0.692 & \\
\hline Perceived & PEU1 & & & & & & & & 0.773 \\
\hline \multirow{4}{*}{$\begin{array}{c}\text { Ease of } \\
\text { Use }\end{array}$} & PEU5 & & & & & & & & 0.758 \\
\hline & PEU4 & & & & & & & & 0.734 \\
\hline & PEU3 & & & & & & & & 0.691 \\
\hline & & SR & PR & TR & AI & $\mathrm{AT}$ & PU & FR & PEU \\
\hline \multicolumn{2}{|l|}{ Eigen Value } & 6.81 & 3.92 & 3.18 & 3.09 & 2.54 & 2.14 & 1.66 & 1.17 \\
\hline \multirow{2}{*}{\multicolumn{2}{|c|}{$\begin{array}{l}\% \text { of variance } \\
\text { Cumulative } \% \text { of variance }\end{array}$}} & 17.93 & 10.32 & 8.38 & 8.13 & 6.67 & 5.63 & 4.37 & 3.09 \\
\hline & & 8.88 & 17.34 & 25.77 & 34.11 & 42.22 & 50.05 & 57.43 & 64.53 \\
\hline \multicolumn{2}{|c|}{ Cronbach Alpha } & 0.821 & 0.853 & 0.844 & 0.919 & 0.819 & 0.868 & 0.786 & 0.835 \\
\hline
\end{tabular}

\section{Measurement Model}

For the assessment of construct validity, Confirmatory Factor Analysis was performed with final thirty three items that were used to measure eight latent variables that included Perceived Ease of Use (PEU), Perceived Usefulness (PU), Perceived Financial Risk (FR), Perceived Security Risk (SR), Perceived Privacy Risk (PR), Perceived Time Risk (TR), Attitude to use Mobile Banking (AT) and Intention Adoption of Mobile Banking (IA). 
The CFA measurement model provides the links between the observed and unobserved variables (Byrne, 2013).

Measurement model relies on the estimation of its model fitness. To measure the overall reliability of heterogeneous but similar items, the literature suggested composite reliability to be a better indicator as compared to cronbach alpha coefficients (Fornell \& Larcker, n.d.; Lin \& Lee, 2004; Molina, Lloréns-Montes, \& Ruiz-Moreno, 2007). Displayed in Table 6 are the results of composite reliability (CR), average variance explained (AVE), and cronbach alpha (CA) values for our eight constructs. The values of CA and CR for all eight factors are above the threshold level of 0.7 representing above average construct validity. Similarly values of AVE are also exhibiting good validity of constructs, except for financial risk, whose value $(0.42)$ is below the threshold of 0.5 . Overall the results indicate an appropriate measurement model (Molina et al., 2007).

Table 6

$\mathrm{CR}, \mathrm{CA}$ and AVE results

\begin{tabular}{lccc}
\hline Variables & CR & CA & AVE \\
\hline Perceived Usefulness & 0.84 & 0.83 & 0.56 \\
Security Risk & 0.81 & 0.80 & 0.51 \\
Privacy Risk & 0.84 & 0.82 & 0.56 \\
Time Risk & 0.85 & 0.84 & 0.53 \\
Financial Risk & 0.74 & 0.75 & 0.42 \\
Perceived Ease of Use & 0.84 & 0.84 & 0.56 \\
Attitude to use & 0.80 & 0.79 & 0.50 \\
Adoption Intention & 0.92 & 0.92 & 0.75 \\
\hline Source: Authors estimation & & &
\end{tabular}

According to (Bagozzi et al., 1991; Byrne, 2013; Kline, 2005; Loehlin, 2004; Marcoulides \& Schumacker, 2001) the most common representation of model fitness is carried out through the Measures of the Normed Chi-square (CMIN/DF), Goodness-of-Fit Index (GFI), Adjusted Goodness-of-Fit Index (AGFI), Normed Fit Index (NFI), Tucker-Lewis Index (TLI), Comparative Fit Index (CFI) and Root Mean Square Error of Approximation (RMSEA) with PCLOSE. The present research utilized these seven measures of model fitness to test the hypothesized model of the study. Table 7 presents the goodness of fit (GOF) indices for our final hypothesized model.

Table 7

Model Fit Indices

\begin{tabular}{lcccccccc}
\hline GOF Indices & CMIN/DF & P-value & GFI & AGFI & NFI & TLI & CFI & $\begin{array}{c}\text { RMSEA } \\
\text { (P-close) }\end{array}$ \\
\hline & & & & & & & & \\
Recommendations & $<5^{a}$ & in-sig & $\geqslant .85^{b}$ & $\geqslant .80^{c}$ & Close to 1 & Close to 1 & $\geqslant .95^{d}$ & $\leqslant .05(>.5)^{e}$ \\
CFA & 1.37 & 0 & 0.915 & 0.895 & 0.894 & 0.964 & 0.969 & $.031(1.0)$ \\
SEM & 1.548 & 0 & 0.901 & 0.881 & 0.877 & 0.946 & 0.952 & $.038(1.0)$ \\
\hline Notes: a = Byrne (2010); b = (Hair et al., 2010) at p. 647 stated that a significant value may be expected (even with good \\
-t), if the sample size is less than 250 with 12 to 30 observed variables; c = Bagozzi and Yi (1988); d = Bentler (1990); e = \\
Browne and Cudeck (1993); All values are rounded to three decimal places.
\end{tabular}

As indicated in Table 7, the value of our normed chi-square (CMIN/DF) is 1.370 which is considerably lower than the recommended value of 5 (Byrne, 2013). However, p-value 
for our hypothesized measurement model is significant. Tanaka (1987) stated that for the models of smaller sample size ( 75 to 200 cases), the chi square test is a reasonable measure of fit, but for models with more cases, (like in the present study where $\mathrm{N}=389$ ) the chi square is almost always statistically significant. The outcomes of other indices also represent above average results with $\mathrm{GFI}=0.915$; AGFI $=0.895 ; \mathrm{NFI}=0.894$; TLI $=0.964$; CFI $=0.969 ;$ and RMSEA $=0.031($ PCLOSE $=1.0)$. The results of all goodness of fit indices satisfied the recommended values from literature (See table 7) and thus suggested that our data fit very well to our model. It should also be noted that our final model included some correlated error terms. The error correlation in our measurement model is done in the way that is accepted by prior researchers, and correlation of error is not performed among different factors (Byrne, Shavelson, \& Muthén, 1989).

\section{Structural Equation Modeling}

The present research was also examined by structural equation modeling (SEM) to verify the frame work and the constructed hypothesis of the study. The structural model investigates the relationship among latent variables (Byrne, 2013). Table 7 displays the results of our hypothesized structural model and holds a good fit evaluated by CMIN/DF $=1.548$; $\mathrm{GFI}=0.901 ; \mathrm{AGFI}=0.881 ; \mathrm{NFI}=0.877 ; \mathrm{TLI}=0.946 ; \mathrm{CFI}=0.952 ;$ and $\mathrm{RMSEA}=$ 0.038 (PCLOSE $=1.0)$. The reported fit indices exceeded their recommended threshold and exhibited good model fitness (See Table 7). Displayed in figure 3, is the structural model for mobile banking intention adoption.

Figure 3: Structural Model for Mobile Banking Adoption Intention

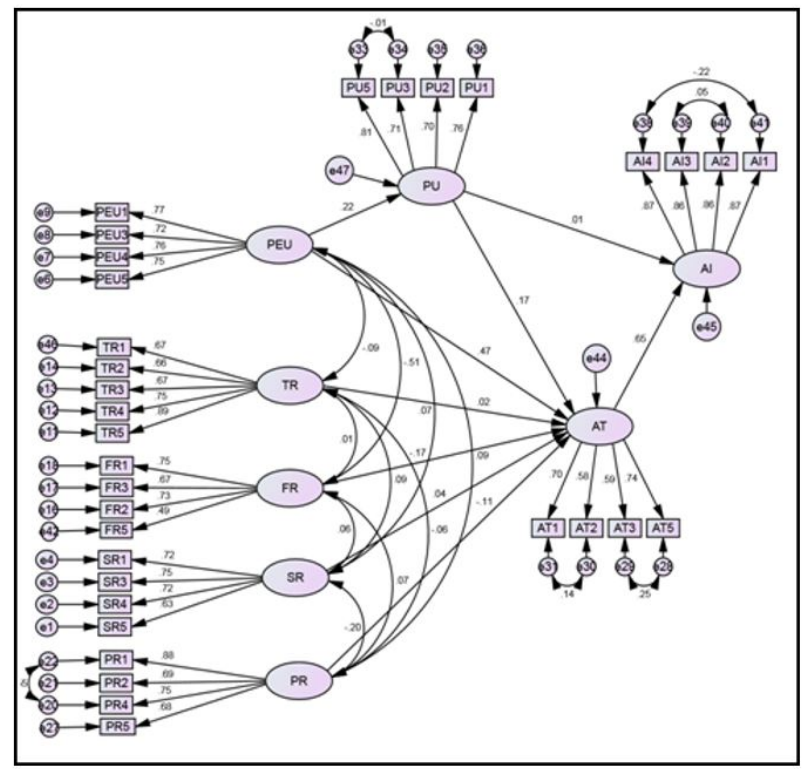


The statistical significance of all determinants for mobile banking intention adoption are projected to set up the validity of the studied hypotheses. Table 8 shows the results of SEM regression paths, standardized regression weights, standard errors, critical ratios, probability values and remarks of the hypothesis. The results suggested the negative significant impact of two risk dimensions i.e. financial risk (FR) and privacy risk $(\mathrm{PR})$ on consumers' attitude to use mobile banking. Perceived ease of use (PEU) and perceived usefulness (PU) however have shown significant positive effect on the attitude to use of mobile banking. Ease of use (PEU) has also shown positive significant impact on the usefulness of mobile banking.

Table 8

SEM Hypothesis Testing

\begin{tabular}{ccccccc}
\hline Hypothesis & Hypothesized Path & Path Coefficient & S.E & C.R & P-Value & Remarks \\
\hline H1 & AT $<--$ PU & 0.098 & 0.034 & 2.858 & 0.004 & Supported \\
H2 & AI $<--$ PU & 0.015 & 0.063 & 0.243 & 0.808 & Not Supported \\
H3 & AT $<--$ PEU & 0.312 & 0.052 & 5.974 & $* * *$ & Supported \\
H4 & PU <-- PEU & 0.257 & 0.07 & 3.674 & $* * *$ & Supported \\
H5 & AT <-- FR & -0.173 & 0.075 & -2.301 & 0.021 & Supported \\
H6 & AT <-- PR & -0.096 & 0.048 & -2.001 & 0.045 & Supported \\
H7 & AT <-- TR & 0.013 & 0.029 & 0.439 & 0.661 & Not Supported \\
H8 & AT <-- SR & 0.052 & 0.075 & 0.689 & 0.491 & Not Supported \\
H9 & AI <-- AT & 1.348 & 0.142 & 9.471 & $* * *$ & Supported \\
\hline Source: Authors Estimation & & & & &
\end{tabular}

Finally, attitude to use mobile banking has shown a positive significant contribution to the adoption intention of mobile banking. Concluding the outcomes of the study, it is established that hypotheses suggesting influence of financial risk, privacy risk, perceived ease of use and perceived usefulness on customers' attitude to use mobile banking are supported. Likewise, the role of ease of use in the usefulness and customers' attitude to use in the adoption intention of mobile banking are also supported in the present study. All the outcomes of our structural regression paths are consistent with the results of (Akturan \& Tezcan, 2012).

\section{Discussion and Conclusion}

This study investigated the empirical argument that the adoption intention of the mobile banking technology of the future prospects is mainly influenced by the attitude towards the usage of mobile banking. This attitude is affected by perceived ease of use, perceived usefulness and perceived risk dimensions. As expected, attitude $(\mathrm{B}=1.348, \mathrm{p}<0.001)$ is found to have a significant positive effect on the adoption intention of mobile banking. The result advocates that the formation of positive attitude about mobile banking should take place before the technology can be accepted. Empirical examination also proved the significant contribution of perceived usefulness $(B=0.098, \mathrm{p}<0.05)$ on the attitude of mobile banking. This is due to the fact that the benefits of mobile banking such as rapid processing, convenient execution of financial transactions, and easy online access to financial information, assist in creating positive attitude of mobile banking among its customers. Perceived ease 
of use $(\mathrm{B}=0.312, \mathrm{p}<0.001)$ is found to play a major role in determining customers' the attitude to use mobile banking. This suggests the importance of perceived ease of use over perceived usefulness (standardized coefficients $\mathrm{B}=0.312, \mathrm{~B}=0.098$ ) in influencing individual attitude towards mobile banking in Pakistan's mobile banking sector. The usefulness perception of mobile banking is evident to be affected by the ease of use perception $(\mathrm{B}=0.257, \mathrm{p}<0.001)$. It highlights the expectation of consumers that using mobile banking should be free of effort. When consumers recognize that learning and using mobile banking is easy, their positive perceptions of usefulness will increase. Attitude towards the mobile banking is also found to be negatively associated with Financial $(\mathrm{B}=0.173, \mathrm{p}<0.05)$ and Privacy risks $(B=0.096, \mathrm{p}<0.05)$. Time risks and security risks, however, failed to influence the attitude of customers' towards mobile banking usage. These two risk dimensions had also been found to be insignificant to affect customers' attitude to use mobile banking in the study of (Akturan \& Tezcan, 2012) in Turkey.

\section{Managerial Implications}

From the managerial point of view, the present research provides valuable insights regarding future prospects of mobile banking. In the adoption of mobile banking, attitude is recognized to play a significant role. Ease of use acts as a major influence on the customers' attitude towards the usage of mobile banking technology. The research findings are useful for drawing the focus of the banks to creating greater ease of use with the emphasis on communicating the higher benefits and convenience of mobile banking to the target customers. Financial and Privacy risks aspects are required to be treated with caution. In that sense, the banks should keep in mind that information and guidance enhance the perceived value added provided by mobile banking and decrease the perceived risks related to the innovation (Laukkanen \& Pasanen, 2008).

\section{Limitations and Future Research}

This study is limited to 389 respondents. Future research can be extended by the use of a larger sample of participants to bring greater insights into the success of mobile banking adoption. The measures of financial risks need to be validated as per the threshold of average variance explained values greater than 0.5. Furthermore, the use of non-users of mobile banking as the respondents can also be modified in future research to include mobile banking users in the sample size. Currently all the commercial banks of Pakistan offer the Internet banking facilities, so the costumers of commercial banks should also be considered for the future research because they have more experience and trust in electronic banking system (Koenig-Lewis et al., 2010). 


\section{References}

Adams, D. A., Nelson, R. R., \& Todd, P. A. (1992). Perceived usefulness, ease of use, and usage of information technology: a replication. MIS Quarterly, 16(2), 227-247.

Afshan, S., \& Sharif, A. (2016). Acceptance of mobile banking framework in Pakistan. Telematics and Informatics, 33(2), 370-387.

Agarwal, R., \& Prasad, J. (1999). Are individual differences germane to the acceptance of new information technologies? Decision sciences, 30(2), 361-391.

Akturan, U., \& Tezcan, N. (2012). Mobile banking adoption of the youth market: Perceptions and intentions. Marketing Intelligence 8 Planning, 30(4), 444-459.

Aldas-Manzano, J., Ruiz-Mafe, C., Sanz-Blas, S., \& Lassala-Navarré, C. (2011). Internet banking loyalty: evaluating the role of trust, satisfaction, perceived risk and frequency of use. The Service Industries Journal, 31(7), 1165-1190.

Ali, M., \& Raza, S. A. (2015). Service quality perception and customer satisfaction in Islamic banks of Pakistan: the modified SERVQUAL model. Total Quality Management $\mathscr{E}$ Business Excellence, 1-19. doi: 10.1080/14783363.2015.1100517

Al Kailani, M., \& Kumar, R. (2011). Investigating uncertainty avoidance and perceived risk for impacting internet buying: a study in three national cultures. International Journal of Business and Management, 6(5), 76-88.

Bagozzi, R. P., Yi, Y., \& Phillips, L. W. (1991). Assessing construct validity in organizational research. Administrative Science Quarterly, 36(3), 421-458.

Barkus, E., Yavorsky, C., \& Foster, J. (2006). Understanding and using advanced statistics. University of Wollongong.

Brown, I., Cajee, Z., Davies, D., \& Stroebel, S. (2003). Cell phone banking: predictors of adoption in South Africa-an exploratory study. International journal of information management, 23(5), 381-394.

Byrne, B. M. (2013). Structural equation modeling with AMOS: Basic concepts, applications, and programming. Routledge.

Byrne, B. M., Shavelson, R. J., \& Muthén, B. (1989). Testing for the equivalence of factor covariance and mean structures: The issue of partial measurement invariance. Psychological Bulletin, 105(3), 456-68.

Chen, C. (2013). Perceived risk, usage frequency of mobile banking services. Managing Service Quality: An International Journal, 23(5), 410-436.

Cope, A. M., Rock, A. M., \& Schmeiser, M. D. (2013). Risk perception, risk tolerance and consumer adoption of mobile banking services. Retrieved from http://papers .ssrn.com/sol3/papers. cfm?abstract_id=2048565

Cox, D. F., \& Rich, S. U. (1964). Perceived risk and consumer decision-making: The case of telephone shopping. Journal of Marketing Research, 1(4), 32-39.

Davis, F. D. (1989). Perceived usefulness, perceived ease of use, and user acceptance of information technology. MIS Quarterly, 13(3), 319-340.

Davis, F. D., Bagozzi, R. P., \& Warshaw, P. R. (1989). User acceptance of computer technology: a comparison of two theoretical models. Management Science, 35(8), 982-1003. 
Fornell, C., \& Larcker, D. F. (n.d.). Evaluating structural equation models with unobservable variables and measurement error. Journal of Marketing Research, 18(1), $39-50$.

Fotopoulos, C. B., \& Psomas, E. L. (2009). The impact of "soft" and "hard" TQM elements on quality management results. International Journal of Quality 63 Reliability Management, 26(2), 150-163.

FRB. (2012). Current use of mobile banking and payments. Retrieved from www.federalreserve.gov/econresdata/mobile-devices/2012-current-use -mobile-banking-payments.htm

Guadagnoli, E., \& Velicer, W. F. (1988). Relation to sample size to the stability of component patterns. Psychological Bulletin, 103(2), 265-278.

Hair, J. F., Black, W. C., Babin, B. J., Anderson, R. E., \& Tatham, R. L. (2006). Multivariate data analysis (6th ed.). Pearson Prentice Hall Upper Saddle River, NJ.

Hair, J. F., Black, W. C., Babin, B. J., Anderson, R. E., \& Tatham, R. L. (2010). Multivariate data analysis (9th ed.). Pearson Prentice Hall Upper Saddle River, NJ.

Heikki, Cruz, P., Barretto Filgueiras Neto, L., Muñoz-Gallego, P., \& Laukkanen, T. (2010). Mobile banking rollout in emerging markets: evidence from Brazil. International Journal of Bank Marketing, 28(5), 342-371.

Karjaluoto, H., Koenig-Lewis, N., Palmer, A., \& Moll, A. (2010). Predicting young consumers' take up of mobile banking services. International Journal of Bank Marketing, 28(5), 410-432.

Karjaluoto, H., Püschel, J., Afonso Mazzon, J., \& Hernandez, J. (2010). Mobile banking: proposition of an integrated adoption intention framework. International Journal of Bank Marketing, 28(5), 389-409.

Karjaluoto, H., Riquelme, H. E., \& Rios, R. E. (2010). The moderating effect of gender in the adoption of mobile banking. International Journal of Bank Marketing, 28(5), 328-341.

Kim, G., Shin, B., \& Lee, H. G. (2009). Understanding dynamics between initial trust and usage intentions of mobile banking. Information Systems Journal, 19(3), 283-311.

Kline, R. B. (2005). Principles and practice of structural equation modeling 2nd edition guilford press. New York.

Koenig-Lewis, N., Palmer, A., \& Moll, A. (2010). Predicting young consumers' take up of mobile banking services. International Journal of Bank Marketing, 28(5), 410-432.

Laforet, S., \& Li, X. (2005). Consumers' attitudes towards online and mobile banking in China. International journal of bank marketing, 23(5), 362-380.

Laukkanen, T. (2007). Customer preferred channel attributes in multi-channel electronic banking. International Journal of Retail \& Distribution Management, 35(5), 393412.

Laukkanen, T., \& Pasanen, M. (2008). Mobile banking innovators and early adopters: How they differ from other online users\&quest. Journal of Financial Services Marketing, 13(2), 86-94.

Lederer, A. L., Maupin, D. J., Sena, M. P., \& Zhuang, Y. (2000). The technology acceptance model and the world wide web. Decision support systems, 29(3), 269-282. 
Leech, N. L., Barrett, K. C., \& Morgan, G. A. (2005). SPSS for intermediate statistics: Use and interpretation. Psychology Press.

Liao, Z., \& Cheung, M. T. (2002). Internet-based e-banking and consumer attitudes: an empirical study. Information \& Management, 39(4), 283-295.

Lin, H.-F., \& Lee, G.-G. (2004). Perceptions of senior managers toward knowledge-sharing behaviour. Management Decision, 42(1), 108-125.

Littler, D., \& Melanthiou, D. (2006). Consumer perceptions of risk and uncertainty and the implications for behaviour towards innovative retail services: the case of internet banking. Journal of Retailing and Consumer Services, 13(6), 431-443.

Loehlin, J. C. (2004). Latent variable models: An introduction to factor, path, and structural equation analysis. Psychology Press.

Lynch, S. M. (2003). Cohort and life-course patterns in the relationship between education and health: A hierarchical approach. Demography, 40(2), 309-331.

Marcoulides, G. A., \& Schumacker, R. E. (2001). New developments and techniques in structural equation modeling. Psychology Press.

Molina, L. M., Lloréns-Montes, J., \& Ruiz-Moreno, A. (2007). Relationship between quality management practices and knowledge transfer. Journal of Operations Management, $25(3), 682-701$.

Pavlou, P. A. (2003). Consumer acceptance of electronic commerce: Integrating trust and risk with the technology acceptance model. International Journal of Electronic Commerce, 7(3), 101-134.

Podsakoff, P. M., MacKenzie, S. B., Lee, J.-Y., \& Podsakoff, N. P. (2003). Common method biases in behavioral research: a critical review of the literature and recommended remedies. Journal of Applied Psychology, 88(5), 879-88.

Püschel, J., Afonso Mazzon, J., \& Mauro, J., C. Hernandez. (2010). Mobile banking: proposition of an integrated adoption intention framework. International Journal of Bank Marketing, 28(5), 389-409.

Raza, S. A., \& Hanif, N. (2013). Factors affecting internet banking adoption among internal and external customers: a case of Pakistan. International Journal of Electronic Finance, 7(1), 82-96.

Schonemann, P. H. (1990). Facts, fictions, and common sense about factors and components. Multivariate Behavioral Research, 25(1), 47-51.

Steiger, J. H. (1990). Structural model evaluation and modification: An interval estimation approach. Multivariate Behavioral Research, 25(2), 173-180.

Sun, S., Goh, T., Fam, K.-S., Xue, Y., \& Xue, Y. (2012). The influence of religion on Islamic mobile phone banking services adoption. Journal of Islamic Marketing, 3(1), 81-98.

Tabachnick, B. G., Fidell, L. S., et al. (2007). Using multivariate statistics.

Tanaka, J. S. (1987). "How big is big enough?": Sample size and goodness of fit in structural equation models with latent variables. Child Development, 58(1), 134-146.

Tobbin, P. (2012). Towards a model of adoption in mobile banking by the unbanked: a qualitative study. Info, 14(5), 74-88.

Vellicer, W. F., \& Jackson, D. N. (1990). Component analysis versus common factor analysis: Some further observations. Multivariate Behavioral Research, 25(1), 97- 
114.

Venkatesh, V., Morris, M. G., Davis, G. B., \& Davis, F. D. (2003). User acceptance of information technology: Toward a unified view. MIS Quarterly, 27(3), 425-478.

Yousafzai, S. Y., Pallister, J. G., \& Foxall, G. R. (2003). A proposed model of e-trust for electronic banking. Technovation, 23(11), 847-860.

Zhou, T. (2011). An empirical examination of initial trust in mobile banking. Internet Research, $21(5), 527-540$. 